\title{
THE TOURISM DEVELOPMENT STRATEGY OF YEH GANGGA BEACH TO BE COMPETITIVE TOURISM PRODUCT AT TABANAN BALI
}

\author{
I Made Bayu Wisnawa, I Ketut Sutapa, I Gusti Agung Bagus Widiantara \\ STIPAR Triatma Jaya
}

\begin{abstract}
This research has a specific purpose: (i) determine the potential of coastal area can be developed as a tourism product, (ii) Knowing constraints are faced in developing the tourism potential, and (iii) determine strategies that can be used in developing the tourism potential of the coast as a creative tourism products Yeh Gangga Beach, Sudimara village, Tabanan Bali. The general objective to be achieved is to improve the performance of the tourism sector in the welfare of society Tabanan through sustainable tourism development by developing creative potential.. The research found that (i) Yeh Gangga Beach has some potential creativity attraction, such as : art market, handycraft,video and photography, music and art performance, scenery, and accomodation; (ii) The main problems encountered are (i)Most strategic land has been switched ownership to investors. The strategy should be applied is (i) Maintain Yeh Gangga Beach as tourist attraction developed Tabanan through local regulations, (ii) increasing public awareness of tourism. The implications are (i) theoretically enriching literature of sustainability in tourism coastal area, (ii)practically could enhance the government to develop coastal tourism in Tabanan Bali.
\end{abstract}

Keywords: Coastal tourism potential, competitive tourism product, sustainability

\section{Introduction}

Bali is an international tourist destination and become the pride of Indonesia. Sparkling tourism in Bali has invited investors to develop their capital. Unfortunately the development of tourism in Bali is still centered on the area that includes the South Bali Badung, Gianyar and Denpasar municipality. Development in the region still relies on physical development of the concept of mass tourism. As a result, the negative impact of the development of tourism in the region began to disrupt the lives of the people perceived the surrounding. One effort that can be done for the development of tourism in the future is to develop the concept of the creative industries is often called creative economy. Creative economy (Suparwoko 2010) developed in various countries showed very encouraging growth, reduced unemployment, increased local revenues, even capable of imaging a region at the international level. Creative economy capable of producing creative products that the market demands, maintain the preservation of resources, and the public welfare even able to lift the image of a region (Levickaite, 2011).

Tabanan, Bali is an area known as the "granary" of Bali which has a variety of resources that can be developed as a tourist destination. However, this 
potential is still not well developed to be able to increase revenue (PAD), which is currently still inadequate financing for development. This condition can be seen in Table 1 where the percentage of revenue of $14.88 \%$, was ranked 4 of 4 districts indicate the high level of dependence of Tabanan local governments to the central government to develop their regions.

Table 1

The Realization and The Percentage of Original Regional Income (PAD) and Balance Fund at Regency / City Region Sarbagita Year 2010 (in million Rupiah)

\begin{tabular}{|c|l|c|c|c|c|}
\hline No & Region & PAD & Balance Fund & $\begin{array}{c}\text { Total } \\
\text { Revenue } \\
\text { Fund }\end{array}$ & $\begin{array}{c}\% \text { PAD to } \\
\text { Total } \\
\text { Regional } \\
\text { Revenue }\end{array}$ \\
\hline 1 & Badung & 979.195 & 322.096 & 1.387 .112 & 70,59 \\
\hline 2 & Denpasar & 260.483 & 499.195 & 903.747 & 28,82 \\
\hline 3 & Gianyar & 153.559 & 468.266 & 771.552 & 19,90 \\
\hline 4 & Tabanan & 116.861 & 513.684 & 784.878 & 14,88 \\
\hline
\end{tabular}

Source : Bali Government (2012)

In the year 2013 there was an increase PAD become Rp.202,741 billion and local revenue amounted Rp.1,214 trillion, with a percentage contribution of revenue (PAD) amounted to 16.70\% (Eka Wiryastuti, 2013). Even in 2012 Tabanan deficit of Rp. 38 billion. This situation shows a lot of potential resources owned Tabanan Bali has not been managed well, including the tourism sector.

Yeh Gangga Beach is one of the beaches that have the potential to be developed as a maritime destination competitiveness. Tabanan currently has 32 leading tourist attraction with a nautical tourist attractions on six attractions, namely Tanah Lot Beach, Kelating Beach, Pasut Beach, Yeh Ganga Beach, and Soka Beach. When compared to other beaches, especially Tanah Lot , Yeh Gangga Beach is not developed optimaly yet. Though this beach has a lot of potential and established as one of the tourism attractions in Tabanan with The Letter of Decision Tabanan Regent Regional Decision No. 470 Tahun 1998, until now the development on this area is still not significant.

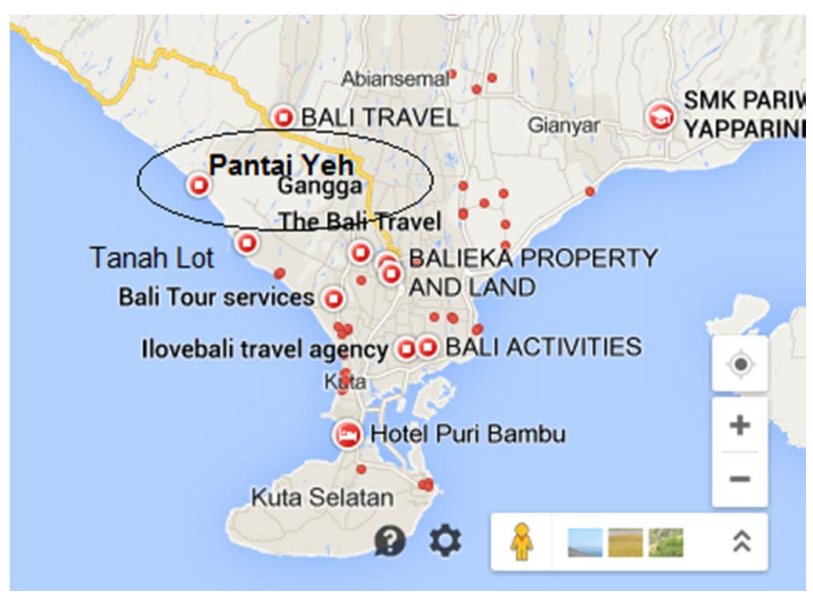




\section{Figure 1 \\ The Location Yeh Ganga Beach which is Strategic}

From Figure 1 above, it can be seen that the Yeh Gangga Beach has a very strategic position is at the circumference of tourism attraction that is very popular in Bali, such as Tanah Lot, Kuta, Abian Semal (Sangeh), and surrounded by various supporting facilities of tourism such as accommodation, food and beverage, and travel agency.

This research is based motivation to support government policies that are promoting the creative economy in the concept of sustainability. The development of tourism in Yeh Gangga Beach is expected to be supported/ accelerated through creative economic activities. The development of tourism through creative economic activity, must be based on the concept of sustainable tourism development, by using the concept of ecotourism so as to reduce the negative impact on the development of tourism itself.

\section{Literature Review}

\section{Concept}

The world has recognized the role of tourism for economic development, the environment, community and social life (Ecles, 1995). It can also be said that tourism is a powerful tool to resolve poverty, employment opportunities and increase foreign exchange (Croes 2006; Scheyvens \& Mornsen, 2008). On the other hand, besides providing good impact tourism has an impact that is not good for the environment. Therefore, the concept of sustainable tourism development based on the preservation of the environment is to be applied in every aspect of tourism development (Sastrayuda, 2010). So that the most important and difficult effort is to change the mindset and behavior in tourism activities for each stakeholder towards environmentally conscious thinking is fundamental to do (Ross \& Wall, 1999). Relevant to the development of sustainable tourism in Indonesia, where each region has a wealth or abundant tourism resources.

Creative economy is a manifestation of the quest for sustainable development through creativity, in which sustainable development is a competitive economic climate and has reserves of renewable resources. The overwhelming message of the creative economy is the utilization of resources infinite, ie, ideas, talents and creativity (Pangestu, 2008).

Ecotourism has many advantages compared to the concept of mass tourism or tourism mass conducted so far, because it contains elements of community development and respecting the ownership, protection and rescue of natural resources, the development of socio-economic aspects, as well as visitors will 
have the added value of travel experience (Honey 2008; Page \& Dowling, 2002). Synergies between communities, businesses, governments, as stakeholders where communities as main actors in the management aspects will provide high level sustainability tourism development fit within the principles of ecotourism (Byrd et al., 2009; Drumm, 1998; Ross \& Wall, 1999), In the end, sustainable tourism can be realized and can improve quality of life without damaging the surrounding environment through the development of products based on creative tourism, creative economy developed by the government today.

\section{Tourism}

Tourism is an activity that can be understood from the many approaches, in Undang-undang No. 10 Tahun 2009 on Tourism, explained that tourism is a wide range of tourist activities and supported a wide range of facilities and services provided by the public, employers and government.

Ismayanti (2010: 223) states Tourism is diverse travel activities undertaken outside the home for more than 24 hours for the purpose of having fun using a variety of tourist facilities, such as transportation and accommodation.

Tourism is defined as travel activities are carried out for the time of the original places to destinations with reasons not to settle or make a living, but just to have fun, satisfy curiousity, spending free time or time off and objectives other purposes (UNESCO 2009 ). One or more people who travel and perform activities related to the tour called Travelers. Travelers can be grouped into two, namely domestic tourists and foreign tourists. Tourists domestic tourists are Indonesian citizens who travel while foreign tourists tourists intended for foreign citizens who travel.

\section{Creative Economy: Definition, Potential, and Challenges}

Murjana Yasa (2010), the creative economy is an activity that is based on the fulfillment of intellectual, skills, talents, and ideas were original. Creative economy is a process of increasing the added value of the exploitation of intellectual property in the form of creativity, expertise and talent of individuals becoming a product that can be commercialized.

Development mindset creative economy can be developed from an understanding of the creative industries. A product derived from the creative process can be characterized as follows. (i) a short life cycle, (ii) Has a relatively high risk, (iii) It has a high margin, (iv) It has a high diversity, (v) Having a high competition and (vi) Easy imitated (Murjanayasa, 2010)

A clearer definition given by UNDP (2008) which formulates that the creative economy is an integrative part of the knowledge that is innovative, creative use of technology, and culture. As described in Figure 2

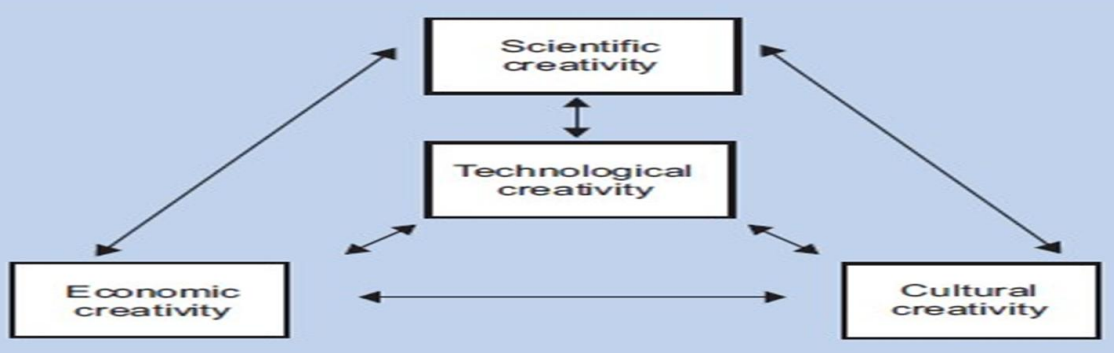


Source : UNDP (2008)

\section{Figure 2 Chart Formulation of the Creative Economy according to the UNDP}

The scope of activities of the creative economy can cover many aspects. Department of Commerce (2008) identified at least 14 sectors included in the creative economy, namely: (i) Advertising, (ii) architecture, (iii) market art products, (iv) Handicraft (handicraft), (v) design, (vi) Fashion, (vii) Film, (viii) video, and photography, (ix) interactive games, (x) Music, (xi) performing arts, (xii) Publishing and printing, (xiii) computer services and software, (xiv) Radio and television, (xv) Research and development

Referring to the figures mentioned above, the creative economy potential and need to be developed in Indonesia. Mari Elka Pangestu in the Convention on the Creative Economy Development 2009-2015 mentions several reasons why the creative industries need to be developed in Indonesia, among others:

1. Provide, contributing significant economic

2. Creating a positive business climate

3. Build the image and identity of the nation

4. Based on the renewable resources

5. Creating innovation and creativity which is a competitive advantage of a nation

6. Provide a positive social impact

\section{Creative Economic Development and Tourism}

Creative economy and the tourism sector are the two things are mutually influential and can synergize if managed properly (Ooi, 2006). The concept of tourism activities can be defined by three factors, ie there must be something to see, something to do, and something to buy (Yoeti, 1985). Something to see associated with attractions in the tourist destination, something to do related to the tourist activity in the tourist area, while related to something to buy typical souvenirs purchased in tourist areas as personal memorabilia \tourists. In three of these components, the creative economy can enter through something to buy with creating innovative products typical of the region.

In the development of the creative economy through the tourism sector which is explained further by Yozcu and İçöz (2010), creativity will stimulate tourist destination to create innovative products that will add value and higher competitiveness compared with other tourist destinations. In terms of tourists, they will feel more interested to visit tourist areas that have distinctive products to then take home as a souvenir. On the other hand, creative products that indirectly will involve individual and enterprise entrepreneurs in contact with the cultural sector. The contiguity will bring a positive impact on efforts to preserve 
the culture and at the same time improve the economy and aesthetics of tourist sites

\section{Methodology}

In this stage, activities steeped in all the information related to physical conditions (basic, built), social conditions (demographic, social relations), economic activities (livelihoods, income, economic activity, sources of income), sociocultural (7 elements of culture), policies and regulations (village official and traditional village) in the village of Yeh Ganga, District of Tabanan, Tabanan, conduct an informal investigation, to develop a formal research framework, collect data, perform tabulation and analysis of data, discussions and draw conclusions and suggestions.

\section{Location}

This study took place in the village of Sudimara, District of Tabanan, Tabanan. Determining the location of this research is done deliberately in view of the uniqueness owned so used as a material consideration. While the determination of the issues raised is based on the lack of research on the issue.

\section{Variables}

The variable / variables to be observed role in these research activities are:

1. Community activities that were potentially creative economy so as to produce creative tourism products which include: (i) Advertising, (ii) architecture, (iii) market art products, (iv) Handicraft (handicraft), (v) design, (vi ) Fashion, (vii) Film, (viii) video, and photography, (ix) interactive games, (x) Music, (xi) performing arts, (xii) Publishing and printing, (xiii) computer services and software, (xiv) Radio and television, (xv) Research and development

2. Ecoturism activity or any activity that contained the potential for ecotourism.

3. SWOT analysis components which include: (i) Strength, (ii) weakness, (iii) opportunities and (iv) threats encountered in the development of tourism potential Yeh Ganga Beach as a creative environmentally sound products in the village Sudimara, District Tabanan regency Tabanan Bali

\section{Respondents}

The respondents of this study were:

1. Rural Community Sudimara well as ordinary people (Krama desa) as well as community leaders (traditional and agencies)

2. Travelers (Tourists) is required with the aimed to assess the tourism potential

3. The Government of Tabanan, especially those in charge of the Tourism Department of the development of tourism potential

4. Travel Bureau, to determine positioning tour packages offered in the Ganges Yeh Beach

6. Academics in the field of tourism product development

\section{Sampling Method}

The focus of this research is aimed at Sudimara Village Community (community leaders and ordinary citizens) as well as tourists visiting in this 
village. Determination of the community sample in this research is by using purposive sampling method ie sampling techniques with particular consideration (Sugiyono, 2008: 124). Considerations used in this study is Sudimara people who have knowledge about the object to be examined. The community criteria to be sampled were:

1. Those who know the depth of information in relation to the problems examined in Sudimara village.

2. They are accepted as related to the group policy determination.

\section{Method of Data Collection}

The data obtained from this study were collected by the method:

1. Questionnaire: data collection is done by providing a complete list of questions that had been prepared in advance to the respondent / sample.

2. In-depth interviews (in-depth interviews)

Data collected by a question and answer directly under the guidance interview to obtain information related to the main issues discussed. As for who will be interviewed are Village Head Sudimara and Tabanan Tourism Goverment.

3. Documentation

The collection of secondary data through documents owned secondary data sources or the relevant government agencies.

4. Observation

Direct observation to the field to determine the internal and external situation Yeh Gangga Beach, Sudimara Village, District Tabanan, Tabanan and the problems encountered.

\section{Data Analysis Technique}

Taking into account the purpose of the research that has been set, then this study tend to use qualitative methods. Once the data is collected, it will be done the analysis and discussion of: (i) to answer the problem first and second, then the information obtained will be compared with the theory and the concept of the creative economy and ecotourism in order to obtain answers regarding the potential and constraints faced, (ii) to answer the third issue, in formulating the strategy will be performed SWOT analysis techniques (Boryk, 2010; Zhang et.al 2013) The results of the discussion will be summarized and given advice

\section{Results and Discussion}

\section{The Potential of Creative Industry and Ecotourism}

Potential of creative industries that can be developed, include: (i) the market for goods and art, because many tourists who visit Yeh Ganga Beach asking about the lack of souvenir shopping facilities. This is certainly an opportunity that can be worked out for the welfare of society (ii) the craft, because basically people Yeh Gangga Beach has the soul of art and artisans (iii) video and photography, as quite a lot of activity taking photos prewedding conducted arround Yeh Ganga Beach (iv ) music, because the village Sudimara has arts organizations such as gongs and angklung, (v) the performing arts.

\section{Potential of Ecotourism}


Yeh Gangga beach has the potential of ecotourism which includes (i) The sights and attractions of the cultural environment, (ii) Landscape (iii) Accommodation and restaurants, (iv) Equipment and supplies for fishing tourism activities (fishing).

\section{Problems Faced in the Development of Tourism Potential to Become Coastal Tourism Product Creative Environmental Yeh Ganga Beach.}

Based on interviews, questionnaires, with the pattern of participatory rural appraisal, there are some obstacles encountered in the development of tourism potential Yeh Ganga Beach to be creative tourism products are environmentally friendly, as follows:

1. Yeh Ganga Beach has gray and black sands. This condition causes Yeh Ganga Beach less exotic, different from Kuta and Nusa Dua Beach, with white sand color. This causes the position Yeh Ganga Beach as a second or third choice for beach tourism.

2. Hygiene is not meet tourism standards.

3. Facilities are limited with low management standards. Until now, the facilities that are available include: accommodation and restaurant, and a bathroom.

4. Access to Yeh Ganga Beach is quite narrow and winding, less supported signpost information board. It is quite difficult for first-time tourists who visit.

5. Local communities have not been equipped with knowledge about tourism, although it already has a hospitality gesture, but it would be nice if the component related community has a basic attitude and knowledge of tourism.

\section{Internal Factor Strategic}

Table 2.

\section{Internal Factor Strategic}

\begin{tabular}{|c|c|c|c|c|c|}
\hline \multirow{2}{*}{\multicolumn{2}{|c|}{ No }} & \multirow{3}{*}{$\begin{array}{l}\text { Internal Factor Strategic } \\
\text { STRENGTH }\end{array}$} & \multicolumn{3}{|c|}{ Value } \\
\hline & & & \multirow[t]{2}{*}{ Weight } & \multirow[t]{2}{*}{ Rating } & \multirow[t]{2}{*}{ Score } \\
\hline $\mathbf{1}$ & & & & & \\
\hline & $\mathrm{a}$ & $\begin{array}{l}\text { Kuta circumference strategic } \\
\text { position, Tanah Lot, Alas } \\
\text { Kedaton, Bedugul }\end{array}$ & 0.15 & 4 & 0.6 \\
\hline & $\mathrm{b}$ & $\begin{array}{lll}\begin{array}{l}\text { Perforated } \\
\text { beautiful }\end{array} & \text { rock } & \text { scenery } \\
\end{array}$ & 0.08 & 3 & 0.24 \\
\hline & $\mathrm{c}$ & Waves suitable for surfing & 0.1 & 3 & 0.3 \\
\hline & $\mathrm{d}$ & $\begin{array}{l}\text { Community friendly, open and } \\
\text { able to receive the difference }\end{array}$ & 0.16 & 4 & 0.64 \\
\hline & $\mathrm{e}$ & $\begin{array}{l}\text { Has the supporting tourism } \\
\text { facilities }\end{array}$ & 0.03 & 2 & 0.06 \\
\hline & $\mathrm{f}$ & $\begin{array}{l}\text { Listed as a tourist attraction } \\
\text { developed by the Government } \\
\text { of Tabanan }\end{array}$ & 0.19 & 4 & 0.76 \\
\hline & & Total & 0.71 & & 2.6 \\
\hline 2 & & WEAKNESS & & & \\
\hline & $\mathrm{a}$ & $\begin{array}{l}\text { Most of the land located along } \\
\text { the coast have been mastered } \\
\text { investor }\end{array}$ & 0.15 & 4 & 0.6 \\
\hline & $\mathrm{b}$ & The beach is less clean & 0.04 & 2 & 0.08 \\
\hline & $\mathrm{c}$ & Most people do not have & 0.03 & 2 & 0.06 \\
\hline
\end{tabular}




\begin{tabular}{|l|l|l|c|c|c|}
\hline \multicolumn{2}{|c|}{ No } & \multicolumn{1}{|c|}{ Internal Factor Strategic } & \multicolumn{3}{c|}{ Value } \\
\cline { 3 - 5 } & keight & Rating & Score \\
\hline & knowledge about tourism & & & 0.06 \\
\hline & d & Less exotic beach sand & 0.02 & 3 & 0.02 \\
\hline & $\begin{array}{l}\text { Tourism facilities are very } \\
\text { limited }\end{array}$ & 0.01 & 2 & 0.04 \\
\hline & $\begin{array}{l}\text { Access into the narrow and } \\
\text { winding }\end{array}$ & 0.04 & 1 & $\mathbf{0 . 8 6}$ \\
\hline & Total & $\mathbf{0 . 2 9}$ & & $\mathbf{3 . 4 6}$ \\
\hline
\end{tabular}

\section{Eksternal Factor Strategic}

Table 3

Eksternal Factor Strategic

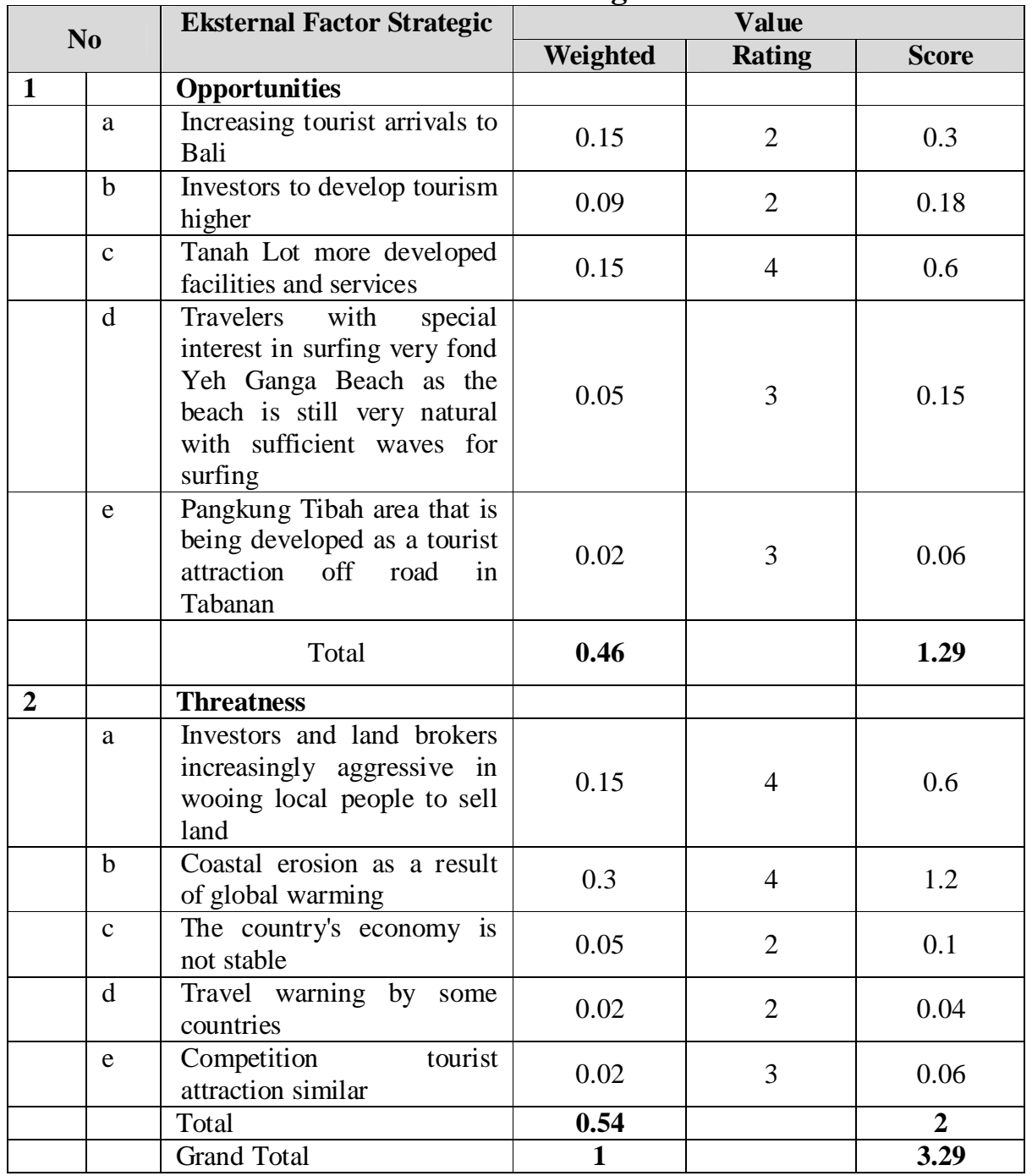




\section{Internal-Eksternal Matrix}

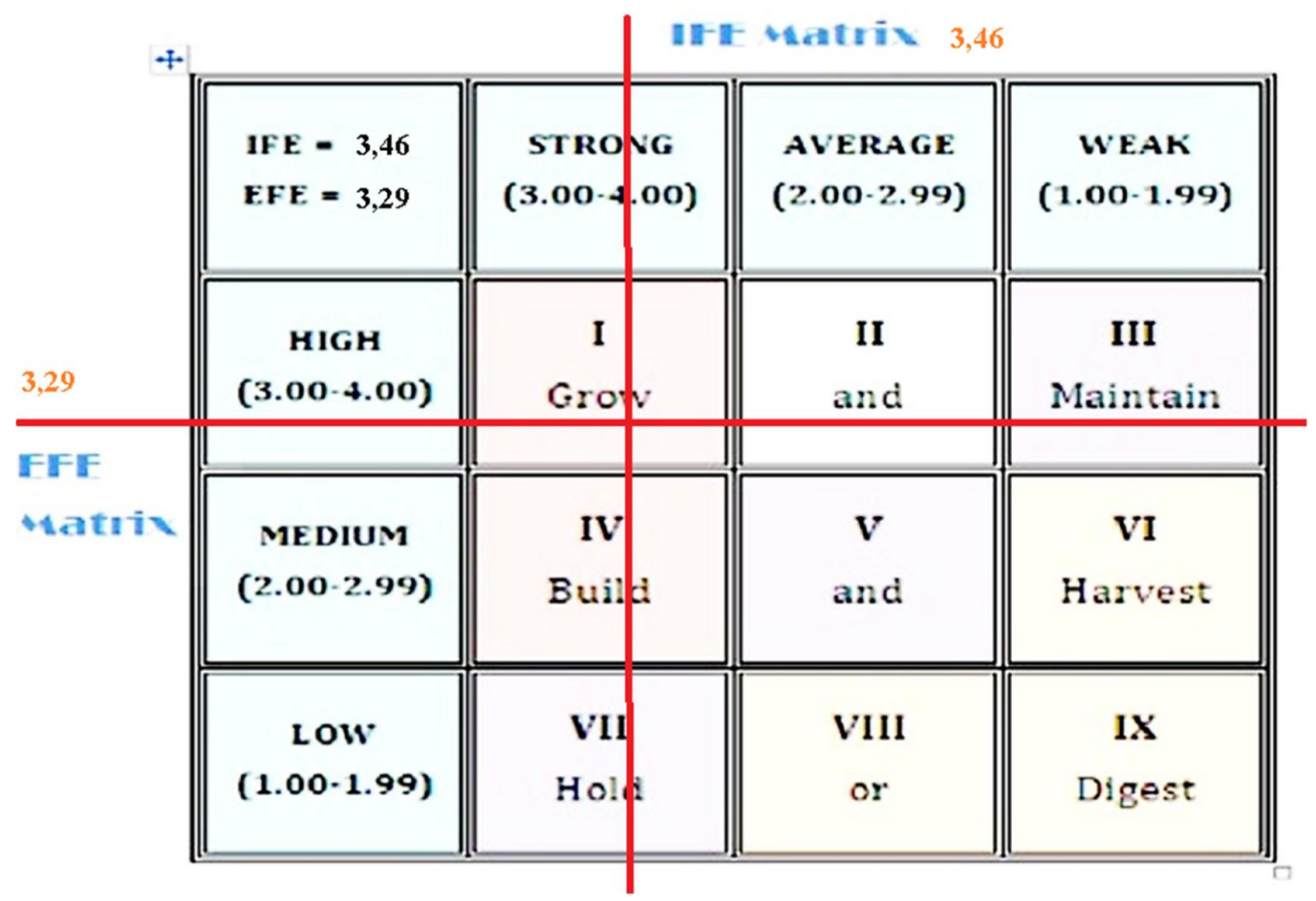

Figure 3

Internal-Eksternal Matrix

The matrix in Figure 3 shows the meeting between the total score of EFAS and IFAS located on the cell into first (I) namely Grow and Maintain (grow and maintain / building). Cells I can be categorized in the growth strategy, by (i) increasing access to a wider market, (ii) develop new products, (iii) improve the services offered.

Therefore Yeh Gangga Beach still has not managed professionally and not well organized, then based on the results of the analysis of internal and external factors, need to be done the following business: (i) Establish a specific organisation that is responsible for the development of tourism Yeh Gangga Beach, (ii) maintaining and utilizing Yeh Gangga Beach regarded as one tourist attraction developed in Tabanan through Decision Letter of Bupati Tabanan No: 470 Tahun 1998, which, along Yeh Gangga Beach used as a major tourist attraction in Tabanan (iii) Promoting Yeh Gangga Beach through the website, travel agency, (iv) development of creative potentials that can generate creative and environmentally sound products, (v) Provide socialization and training on tourism awareness.

Policies to Applied in Tourism Development Yeh Gangga Beach.

Based on the identification of internal-external factors and matrix grand strategy, then formulated the strategy is to Grow and Maintain. However, the future strategy that can be implemented properly, there should be further study in greater depth with the Focus Group Discussion 
Focus Group Discussion with emphasis on the Grow and Maintain strategy, developing policies to the strategy used for the development of tourism potential Yeh Ganga Beach Tourism Product Being Creative in Tabanan Bali as follows:

1. Utilizing status Yeh Ganga Beach as one of the main tourist attraction nautical developed in Tabanan to achieve tourism development funding.

2. Tourism awareness group formed specifically addressing the potential development of tourism in Yeh Gangga Beach

3. Establish cooperation with the manager of Otorita Tanah Lot Beach, Pangkung Tibah and Kedungu as well as Travel bureau in order to go in itenary tour

4. Establish cooperation with academia, especially the College of Tourism, University tha study tourism in order to practice the science of Tri Dharma Community Service in Yeh Gangga Beach, in creating a society of tourism awareness

5. Hold festivals as a means of promotion Yeh Ganga Beach

6. Not sold land to investors, but only contracting

7. Increase the cleanliness of Yeh Gangga Beach

8. Increase the number and quality of tourism facilities in Yeh Gangga Beach, especially for the activities of surfing and fishing

9. Adding signpost, along the road to Yeh Ganga Beach

\section{References}

Anonim.(2014). Bali Tolak Abrasi.http://m.mpujayaprema.com. Diakses pada 25 Agustus 2014. Pukul 13.45 Wita.

Anonim.(2013). Investor Jakarta 'Kuasai'Pantai Tabanan.Harian Fajar Bali. 18 Maret 2013.

Anonim.(2009). Panduan Dasar Pelaksanaan Ekowisata.UNESCO, http://unesdoc.unesco.org/images/0018/001855/185506ind.pdf

Anonim.(2013). Tabanan Defisit 38 Milyar.http://suluhbali.co/breakingnews/tabanan-defisit-rp-38-miliar/. Pada tanggal 12 Desember 2013 jam $12: 24$

Boryk, O. (2010). Analysis Of Tourist Recreational Potential Of Ternopil Region. Economics \& Sociology, 3(1), 143-149. Retrieved From http://search.proquest.com/docview/1038947922?accountid=62693

Byrd, E. T., Cardenas, D. A., \& Dregalla, S. E. (2009). Differences in stakeholder attitudes of tourism development and the natural environment.e-Review of Tourism Research, 7 (2).

Cornwall, A., \& Pratt, G. (2011). The use and abuse of participatory rural appraisal: Reflections from practice. Agriculture and Human Values, 28(2), 263-272. doi:http://dx.doi.org/10.1007/s10460-010-9262-1

Croes, R. R. (2006). A paradigm shift to a new strategy for small island economies: embracing demand side economics for value enhancement and long term economic stability. Tourism Management, 27 (3).

Drumm, A. (1998). New approaches to community-based ecotourism management.Learning from Ecuador.In K. Lindberg, M. E. Wood, \& D. E. Hawkins (Eds.). 
Eccles, G. (1995). Marketing Sustainable Development and International Tourism.International Journal of Contemporary Hospitality Management, 7 (7).

Honey, M. (2008). Ecotourism and sustainable development: Who own paradise? 2nd ed. Washington, DC: Island Press.

Ismayanti. (2010). Pengantar Pariwisata, Jakarta :Grasindo.

Lanya. 1995 Buku Pedoman kerja Pariwisata (BPKM) Mata Kuliah Dasar - Dasar Pengembangan Wilayah, Denpasar : Fakultas Pertanian Unud.

Manurung. (2002). Ecotourism in Indonesia. In: Hundloe, T (ed.). Linking Green Productivity to Ecotourism : Experiences in the Asia-Pacific Region. Asian Productivity Organization (APO), Tokyo, Japan. 98-103

Murjanayasa, I Wayan. (2010).Eonomi Kreatif:Konsep, Metodologi danImplementasi (Sebuah Pemikiran Awal).http://www.scribd.com/doc/81566623/EKONOMI-KREATIF-2009

Ooi, Can-Seng . (2006). "Tourism and the Creative Economy in Singapore"

Page, S. J., \& Dowling, R. K. (2002).Ecotourism (themes in tourism).New York: Prentice Hall.

Pangestu, Mari Elka . (2008). "Pengembangan Ekonomi Kreatif Indonesia 2025", disampaikan dalam Konvensi Pengembangan Ekonomi Kreatif 2009-2015 yang diselenggarakan pada Pekan Produk Budaya Indonesia 2008, JCC, 4 -8 Juni $2008 \quad$ http://indonesiakreatif.net/cms/wpcontent/uploads/2009/10/Buku-3-Pengembangan-Industri-Kreatif-MenujuVisi-Ekonomi-Kreatif-Indonesia-2025.pdf

Pitana, I G. (2005). Sosiologi Pariwisata, Yogyakarta: Andi Offset

Putra,Agus Muriawan. (2009). Sosialisasi Konsep Pariwisata Berkelanjutan Dalam Pengelolaan Objek Wisata Pantai Yeh Gangga Kabupaten Tabanan. Jurnal Udayana Mengabdi Vol.8, No 1_April 2009.

Ross, S., \& Wall, G. (1999). Ecotourism: towards congruence between theory and practice. Tourism Management, 20 (1).

Sanjaya, I Komang Gede. (2015).Pantai Yeh Gangga Layak Sebagai Obyek Wisata Kuliner. Http://baliolnews.com. Diakses pada Senin 23 Februari 2015 pukul 10.05 Am.

Sastrayuda, Gumelar S. (2010). Konsep pengembangan kawasan desa wisata. (http://www.google.co.id.file.upi.edu/Direktori/Gumelar_S).

Scheyvens, R., \& Mornsen, J. H. (2008). Tourism and poverty reduction: issues for small island states. Tourism Geographies, 10 (1).

Sugiyono.(2008). Metode Penelitian Bisnis, Cetakan Ke-Dua Belas, Penerbit Alfabeta, Bandung.

Suparwoko. (2010). Pengembangan Ekonomi Kreatif sebagai penggerak industry pariwisata, Jakarta : Universitas Islam Indonesia.

UNDP (2008). Creative Economy Report 2008.http://unctad.org/es/Docs/ditc20082cer en.pdf

UU Pariwisata No.10/2009 tentang Pariwisata.

Wood, Megan Epler.2002.Ecotourism, Principles, Practise and Policies for Sustainability UNEP and TIES Publication. http://www.pnuma.org/eficienciarecursos/documentos/Ecotourism1.pdf

Yoeti, Oka A. (1985). Pengantar Ilmu Pariwisata, Bandung: Angkasa 
Yozcu, Özen Kırant dan İçöz, Orhan . (2010). “A Model Proposal on the Use of Creative Tourism Experiences in Congress Tourism and the Congress Marketing Mix”, PASOS, Vol. 8(3) Special Issue 2010 
